\title{
Een carrière als sociaal geneeskundige: een optie voor de huidige geneeskundestudent?
}

\author{
Marc B. M. Soethout · Allard J. van der Beek
}

Geaccepteerd op: 8 January 2021 / Published online: 29 January 2021

(C) The Author(s) 2021

Samenvatting Met een retrospectief, beschrijvend onderzoek wilden we inzicht verkrijgen in de belangstelling voor en de bekendheid met de beroepen van bedrijfsarts, verzekeringsarts en jeugdarts onder geneeskundestudenten. Tevens wilden we weten welk beeld van deze beroepen bestaat, en in hoeverre dat beeld overeenkomt met het gewenste beroepsbeeld van aanstaand arts. Alle studenten geneeskunde van Amsterdam UMC, locatie VUmc, werden in 2009 en 2019 op de laatste dag van het coschap sociale geneeskunde gevraagd een identieke vragenlijst in te vullen over hun voorkeur voor de beroepen van bedrijfsarts, verzekeringsarts en jeugdarts. Tevens werd gevraagd naar de mate van aantrekkelijkheid van diverse kenmerken van het toekomstige beroep van arts en in hoeverre deze kenmerken van toepassing zijn op de beroepen van bedrijfsarts, verzekeringsarts en jeugdarts. In 2019 werden 145 studenten bereid gevonden deel te nemen aan dit onderzoek (2009: 125 studenten). De beroepen van bedrijfsarts, verzekeringsarts en jeugdarts zijn niet erg populair onder studenten geneeskunde. De belangstelling voor de beroepen van bedrijfsarts en verzekeringsarts lijkt de laatste tien jaar licht toegenomen, maar die voor jeugdarts lijkt wat achter te blijven. Studenten hebben ook weinig kennis van de inhoud van deze beroepen. De meeste kenmerken die studenten aantrekkelijk vinden voor hun latere beroepsoefening zijn niet van toepassing op de beroepen van bedrijfsarts, verzekeringsarts en jeugdarts. Een betere beeldvorming van de beroepen van bedrijfsarts, verzekeringsarts en jeugdarts in de geneeskundeopleiding is wenselijk, naast een aantrekkelijker beroepsbeeld van deze beroepen om

Dr. M. B. M. Soethout ( $₫)$ · Prof.dr. A. J. van der Beek afdeling Public and Occupational Health, Amsterdam UMC, locatie VUmc, Amsterdam, Nederland

mbm.soethout@amsterdamumc.nl voldoende instroom in het werkveld van de sociale geneeskunde in de nabije toekomst te waarborgen.

Trefwoorden beroepskeuze beroepsbeeld . studenten geneeskunde

A career as public health or occupational health physician: an option for the current medical student?

Abstract We studied the interest in and awareness of the professions of occupational health physician, health insurance physician and youth health physician among medical students. The aim was also to gain insight into the professional image that exists of these professions, and to what extent that image corresponds to the desired professional image of a future medical doctor. We conducted a retrospective study among medical students from Amsterdam University Medical Center in 2009 and 2019. Students were asked to complete an identical questionnaire in 2009 and 2019 about their career preference for the professions of occupational health physician, insurance health physician and youth health physician on the last day of their public and occupational health clerkship. We also asked about the degree of attractiveness of various characteristics of the future profession of a physician and to what extent these characteristics apply to the professions of occupational health physician, insurance health physician and youth health physician. In 2019, 145 students participated in this study (2009: 125 students). The professions of occupational health physician, insurance health physician and youth health physician are not very popular for medical students. A career choice in the professions of occupational health physician and insurance health physician seems to have increased slightly in the last decade, but a career choice in youth health physician 
seems to be lagging behind. Students also have little knowledge of the content of these professions. Most characteristics that students find attractive for their later professional practice do not apply to the professions of occupational health physician, insurance health physician and youth health physician. A better professional image of the professions of occupational health physician, insurance health physician and youth health physician in undergraduate medical training is desirable, as well as a more attractive professional image of these professions for medical students in order to get an adequate inflow into the field of public and occupational health medicine in the near future.

Keywords Career choice · Professional image · Medical students

\section{Inleiding}

Sociale geneeskunde is in Nederland qua omvang het derde geneeskundig specialisme, na huisartsgeneeskunde en psychiatrie. In 2019 waren er in Nederland 3.320 geregistreerde sociaalgeneeskundig specialisten, wat ongeveer $7 \%$ is van het totale aantal geneeskundig specialisten [1].

Sociale geneeskunde bestaat uit de hoofdstromen Arbeid en Gezondheid en Maatschappij en Gezondheid, en omvat een vierjarige postacademische opleiding [2]. De hoofdstroom Arbeid en Gezondheid betreft de specialismen bedrijfsgeneeskunde en verzekeringsgeneeskunde. De hoofdstroom Maatschappij en Gezondheid omvat een eerste fase van twee jaar met een achttal praktijkgerichte profielen, waaronder het profiel jeugdarts, en een tweejarige vervolgopleiding die leidt tot het specialisme arts Maatschappij en Gezondheid. Binnen het specialisme Arbeid en Gezondheid waren in 20191.683 artsen geregistreerd als bedrijfsarts en 963 artsen als verzekeringsarts. Binnen het domein Maatschappij en Gezondheid vormen de jeugdartsen met 1.053 artsen de grootste groep, gevolgd door 674 artsen Maatschappij en Gezondheid [2].

Eerder onderzoek liet zien dat in Nederland de beroepsvoorkeur van studenten voor sociale geneeskunde laag is, maar ook in andere landen blijkt dat het geval te zijn [3-7]. Inhoudelijk zijn sociale omstandigheden, zoals het werken conform kantoortijden, mogelijkheden tot parttime werken en gezinsomstandigheden, belangrijke redenen om voor een sociaalgeneeskundige carrière te kiezen $[8,9]$. De beroepsvoorkeur wordt voor een groot deel gevormd gedurende de coassistentschappen van de basisartsopleiding, waarbij de beeldvorming van het toekomstige beroep door diverse praktijkcontacten wordt gevormd [10].

Aan het eind van vijfde studiejaar van de zesjarige artsopleiding van het Amsterdam UMC, locatie VUmc, is het verplichte twee weken durende coassistentschap sociale geneeskunde opgenomen.
Het coassistentschap omvat facultair onderwijs en een praktijkstage bij diverse sociaalgeneeskundige instellingen. Circa $40 \%$ van de studenten brengt een praktijkstage door in de bedrijfsgezondheidszorg, circa $10 \%$ in de verzekeringsgeneeskunde en circa $50 \%$ in de hoofdstroom Maatschappij en Gezondheid (in het bijzonder jeugdgezondheidszorg). Studenten kunnen vooraf een voorkeur opgegeven voor een bepaalde praktijkstage. Ruim 50\% van de studenten maakt gebruik van de mogelijkheid om een voorkeur aan te geven, die grotendeels ook vervuld kan worden. Jeugdgezondheidszorg wordt hierbij het meest genoemd, gevolgd door bedrijfsgeneeskunde en verzekeringsgeneeskunde.

In Amsterdam UMC wordt al enige tijd onderzoek gedaan naar determinanten van de studieloopbaan van studenten, met een accent op beroepskeuze. Dit onderzoek onder studenten richt zich op de volgende vraagstellingen:

- Hoe groot is de belangstelling voor en de bekendheid met de beroepen van bedrijfsarts, verzekeringsarts en jeugdarts?

- Welk beroepsbeeld bestaat er van deze beroepen, en in hoeverre komt dat beeld overeen met het gewenste beroepsbeeld van aanstaand arts?

\section{Methode}

In de periode van 1 september 2018 tot 31 maart 2019 ontvingen alle 153 vijfdejaars geneeskunde studenten van Amsterdam UMC, locatie VUmc, aan het eind van hun coassistentschap sociale geneeskunde een vragenlijst over beroepsvoorkeuren en beroepskenmerken. De studenten ontvingen de vragenlijst tijdens een afsluitende facultaire bijeenkomst van het coassistentschap sociale geneeskunde en vulden de vragenlijst ter plekke in. Voorafgaand aan de vragenlijstafname werd van alle studenten informed consent verkregen. De vragenlijst en methode waren identiek aan die van onderzoek van tien jaar geleden naar de beroepsvoorkeur van geneeskundestudenten voor jeugdarts, verzekeringsarts en bedrijfsarts $(n=125)[4$, 5]. De vragenlijst was ontworpen als onderdeel van een groter onderzoek naar carrièrekeuze en beïnvloedende factoren dat sinds 2002 door Amsterdam UMC wordt uitgevoerd [11]. Het coassistentschap is in deze periode qua opzet en plaats in het curriculum niet veranderd en ook in het bacheloronderwijs is nauwelijks verandering opgetreden.

Aan studenten werd gevraagd voor elk van de beroepen bedrijfsarts, verzekeringsarts en jeugdarts op een vijfpuntslikertschaal (respectievelijk ' $1=$ absoluut niet', ' 2 = liever niet', ' 3 = geen mening', ' 4 = ik denk erover' en ' $5=$ graag') aan te geven of ze dit zouden willen uitoefenen. Tevens werd voor elk van deze drie beroepen gevraagd op een vijfpuntslikertschaal (respectievelijk ' 1 = vrijwel niet', ' $2=$ weinig', ' 3 = matig', ' 4 = goed' en ' $5=$ zeer goed') aan te geven of ze bekend waren met dit beroep. Ten slotte werd gevraagd om 
van 47 beroepskenmerken aan te geven in hoeverre ze dit kenmerk aantrekkelijk vonden voor hun latere beroepsuitoefening als arts, en in welke mate ze dit kenmerk van toepassing vonden op de beroepen van bedrijfsarts, verzekeringsarts en jeugdarts.

De beroepskenmerken hadden betrekking op vier domeinen:

I. vereiste kennis en vaardigheden;

II. aard van het medisch professioneel handelen;

III. type patiënten, contacten en aandoeningen;

IV. kenmerken van het dagelijkse werk.

De classificatie liep van 1 tot 5 ( $1=$ zeer weinig aantrekkelijk c.q. zeer weinig van toepassing en $5=$ zeer aantrekkelijk c.q. zeer sterk van toepassing).

Voor de analyse werd een onderscheid gemaakt naar afnamejaar voor de gehele studentengroep, en voor de deelgroepen naar het soort praktijkstage (bedrijfsgeneeskunde, verzekeringsgeneeskunde en jeugdgezondheidszorg). Om inzicht te krijgen in de mate van aantrekkelijkheid voor de latere beroepsuitoefening en de mate van toepasbaarheid op het beroep van bedrijfsarts, verzekeringsarts en jeugdarts werden per beroepskenmerk gemiddelden berekend en werd op grond hiervan een rangorde naar aantrekkelijkheid en toepasbaarheid opgesteld.

Tevens werden verschilscores berekend tussen de gemiddelde score van de antwoorden op de diverse kenmerken qua aantrekkelijkheid van de latere beroepsuitoefening als arts en de corresponderende antwoorden op de toepasselijkheid van deze kenmerken op het beroep van bedrijfsarts, verzekeringsarts en jeugdarts. Een positieve verschilscore wil zeggen dat het kenmerk volgens de studenten aantrekkelijker is voor de toekomstige beroepsuitoefening als arts en minder toepasselijk is op het beroep van respectievelijk bedrijfsarts, verzekeringsarts en jeugdarts. Afwijkingen kunnen maximaal 4 punten bedragen (als een score 1 is voor de aantrekkelijkheid van het toekomstige beroep en 5 voor toepasselijkheid op het beroep van bedrijfsarts, verzekeringsarts en jeugdarts, of vice versa). Een grote positieve verschilscore wil dus zeggen dat studenten het betreffende aspect zeer aantrekkelijk vinden in relatie tot het latere beroep van arts, maar (zeer) weinig van toepassing vinden op het beroep van sociaal geneeskundige. Omgekeerd wil een grote negatieve verschilscore zeggen dat studenten het betreffende aspect (zeer) weinig aantrekkelijk vinden in relatie tot het latere beroep van arts, maar zeer van toepassing vinden op het beroep van sociaal geneeskundige. Statistische analyse werd verricht met het programma IBM-SPSS 24 en verschillen werden getoetst met de t-toets en chi-kwadraattoets. Naast een descriptieve weergave van de resultaten werden steeds geslachtsverschillen en verschillen tussen 2019 en 2009 getoetst.

\section{Resultaten}

In totaal ontvingen 153 studenten de vragenlijst, van wie er 145 (respons: 95\%) de lijst retourneerden (2009: $n=125$, respons $97 \%$ ). De geslachtsverdeling onder de respondenten was conform die van de totale populatie geneeskundestudenten (2019: 34\% man, 65\% vrouw; 2009: $26 \%$ man en $73 \%$ vrouw).

Figuur 1 laat zien dat circa $15 \%$ van alle studenten in 2019 graag bedrijfsarts of jeugdarts wil worden of hierover denkt. Voor verzekeringsgeneeskunde is dit percentage $6 \%$. Maar liefst $66 \%$ respectievelijk $78 \%$ en $67 \%$ van de studenten wilde liever geen of absoluut geen bedrijfsarts, verzekeringsarts of jeugdarts worden. Alleen voor jeugdarts werd een geslachtsverschil gevonden (bedrijfsarts: man $65 \%$, vrouw $66 \%$, verzekeringsarts: man $78 \%$, vrouw $79 \%$ en jeugdarts: man: $79 \%$, vrouw $61 \%, p=0,02)$. Circa $10 \%(n=13)$ van de respondenten had in 2019 naast een positieve voorkeur voor een discipline ('graag' of 'denkt er over na'), ook een positieve voorkeur voor een of meer andere sociaalgeneeskundige beroepen (2009: 5\%). Van deze dertien respondenten hadden er zes $(46 \%)$ een positieve voorkeur voor de combinatie bedrijfsarts en/of verzekeringsarts, en vier een positieve voorkeur voor de combinatie jeugdarts en/of bedrijfsarts (30\%) (niet in de tabel).

Figuur 1 Mate van voorkeur voor de beroepen van bedrijfsarts, verzekeringsarts en jeugdarts volgens studenten geneeskunde in $2019(n=145)$

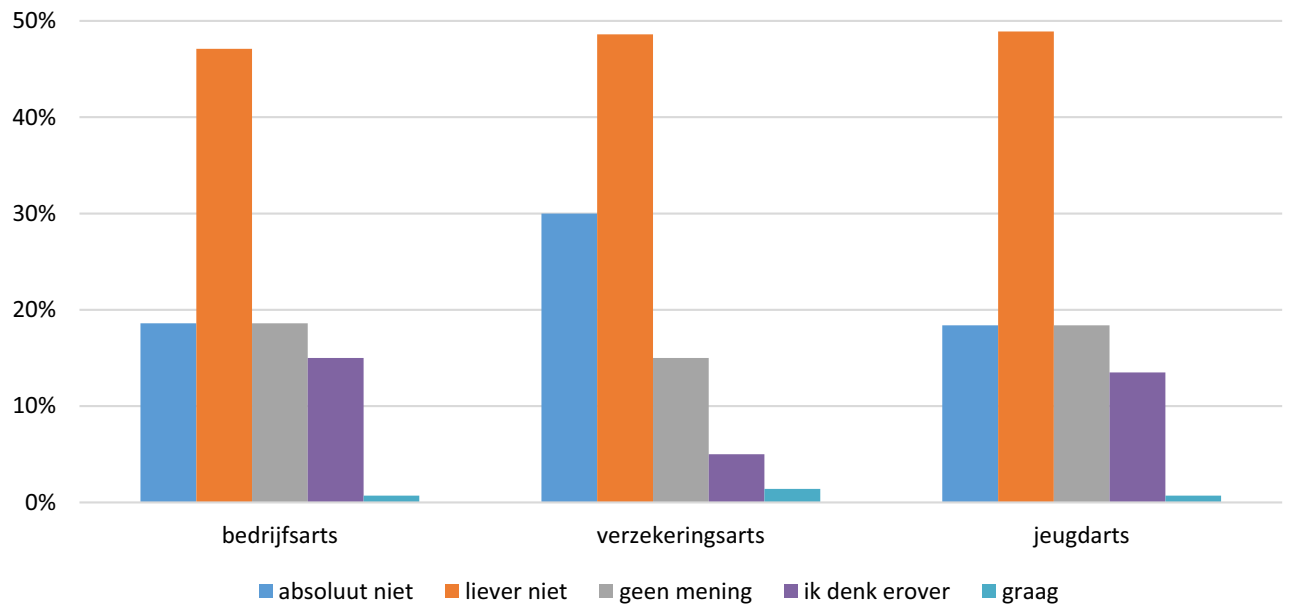


Figuur 2 Mate van kennis van de beroepen van bedrijfsarts, verzekeringsarts en jeugdarts volgens studenten geneeskunde in $2019(n=145)$
$50 \%$

$40 \%$

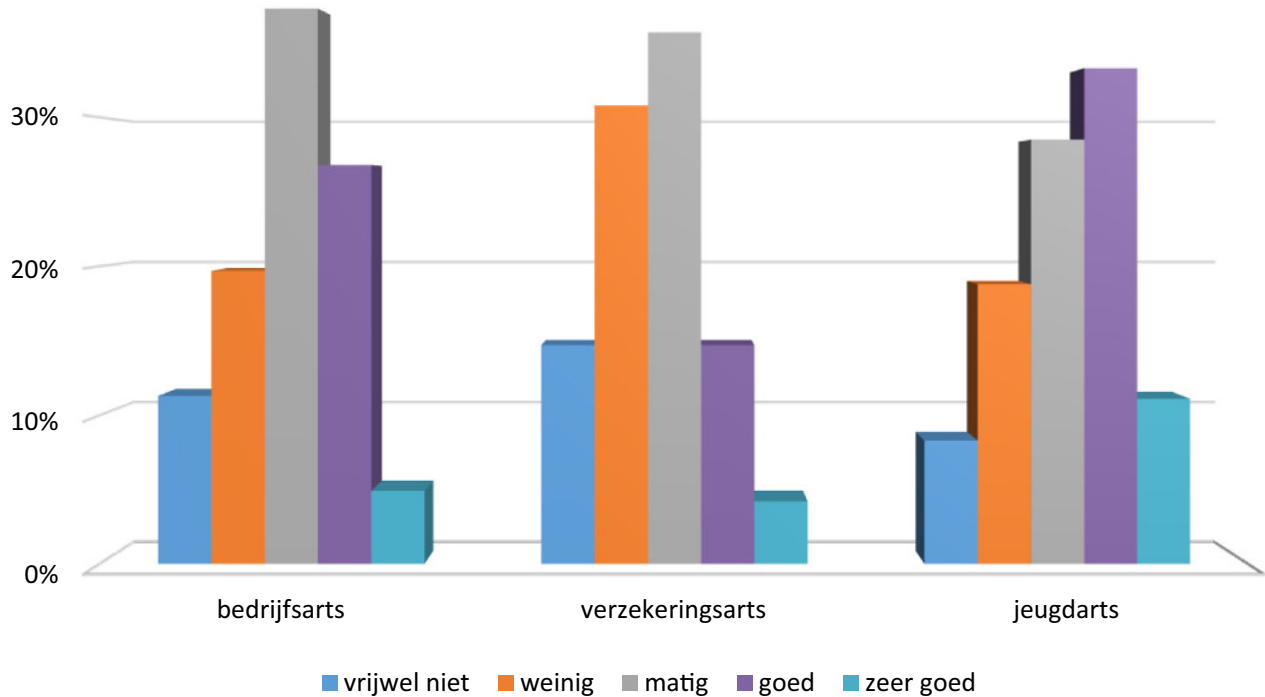

Voor studenten die in 2019 een praktijkstage bedrijfsgeneeskunde, verzekeringsgeneeskunde of jeugdgezondheidszorg in het coassistentschap doorlopen hebben (respectievelijk $n=33, n=16$ en $n=46)$ waren deze percentages respectievelijk 42\% (2009: 18\%), 31\% (2009: 36\%) en $17 \%$ (2009: 46\%) (niet in de tabel).

De gemiddelde voorkeur voor het beroep van bedrijfsarts en verzekeringsarts was toegenomen in vergelijking met tien jaar geleden (bedrijfsarts 2009: 2,03 en 2019:2,32, $p=0,02$, verzekeringsarts 2009: 1,73 en 2019: $1,99, p=0,02$ ). De gemiddelde voorkeur voor het beroep van jeugdarts was echter afgenomen in vergelijking met tien jaar geleden (2009: 2,61 en 2019:2,29, $p=0,01$ ). De gemiddelde voorkeur voor het beroep van jeugdarts was groter voor vrouwen dan voor mannen in zowel 2019 als 2009 (2019: man 2,04, vrouw: $2,42, p=0,02$ en 2009: $\operatorname{man} 2,14$, vrouw 2,77 , $p<0,01)$. Voor bedrijfsgeneeskunde en verzekeringsgeneeskunde waren er geen significante verschillen tussen mannen en vrouwen (niet in de tabel).

Uit fig. 2 blijkt dat $32 \%$ van alle responderende studenten in 2019 naar eigen zeggen goed tot zeer goed bekend was met het beroep van bedrijfsarts. Voor de beroepen van verzekeringsarts en jeugdarts was dit respectievelijk $19 \%$ en $44 \%$. Voor studenten die

Tabel 1 Top 10 van meest aantrekkelijke kenmerken van het toekomstige medisch beroep vergeleken met de kenmerken die het meest van toepassing werden geacht op de beroepen van bedrijfsarts, verzekeringsarts en jeugdarts, volgens studenten geneeskunde in 2019 ( $n=145)$

\begin{tabular}{|c|c|c|c|}
\hline $\begin{array}{l}\text { Meest aantrekkelijke kenmerken } \\
\text { medisch beroep } 2019\end{array}$ & $\begin{array}{l}\text { Meest toepasselijk op het beroep van } \\
\text { bedrijfsarts }\end{array}$ & $\begin{array}{l}\text { Meest toepasselijk op het beroep van } \\
\text { verzekeringsarts }\end{array}$ & $\begin{array}{l}\text { Meest toepasselijk op het beroep van } \\
\text { jeugdarts }\end{array}$ \\
\hline 1. Kunnen communiceren & 1. Psychosociale aandoeningen & 1. Parttimewerkmogelijkheden & 1. Jonge patiënten \\
\hline 2. Behandelen & 2. Parttimewerkmogelijkheden & 2. Routinewerk & 2. Voorlichten \\
\hline 3. Redeneervaardigheid & 3. Praatwerk & 3. Chronische aandoeningen & 3. Gezonde personen \\
\hline $\begin{array}{l}\text { 4. Vertrouwensrelatie opbouwen } \\
\text { met patiënten }\end{array}$ & $\begin{array}{l}\text { 4. Kennis van de organisatie van de } \\
\text { gezondheidszorg }\end{array}$ & $\begin{array}{l}\text { 4. Kennis van de organisatie van de } \\
\text { gezondheidszorg }\end{array}$ & 4. Parttimewerkmogelijkheden \\
\hline 5. Zichtbare resultaten & 5. Kunnen communiceren & 5. Psychosociale aandoeningen & 5. Voorkomen van ziekte \\
\hline 6. Diversiteit van werkzaamheden & 6. Chronische aandoeningen & 6. Kunnen communiceren & 6. Kennis van epidemiologie \\
\hline 7. Diagnostiek & $\begin{array}{l}\text { 7. Kennis van de psychosociale en } \\
\text { culturele achtergronden }\end{array}$ & 7. Praatwerk & 7. Routinewerk \\
\hline 8. Kennis van pathologie & 8. Voorlichten & $\begin{array}{l}\text { 8. Kennis van de psychosociale en } \\
\text { culturele achtergronden }\end{array}$ & 8. Kunnen communiceren \\
\hline 9. Praatwerk & 9. Begeleiding bij ziekte & 9. Kennis van epidemiologie & $\begin{array}{l}\text { 9. Kennis van de psychosociale en } \\
\text { culturele achtergronden }\end{array}$ \\
\hline 10. Bestrijden van pijn en ongemak & 10. Routinewerk & 10. Meerdere aandoeningen tegelijk & 10. Praatwerk \\
\hline
\end{tabular}


Figuur 3 Aantrekkelijkheid van 47 aspecten van het medisch beroep, en de beroepen van bedrijfsarts, verzekeringsarts en jeugdarts volgens studenten geneeskunde in 2019 $(n=145)$, op een vijfpuntschaal van 1 (zeer weinig aantrekkelijk) tot 5 (zeer aantrekkelijk)

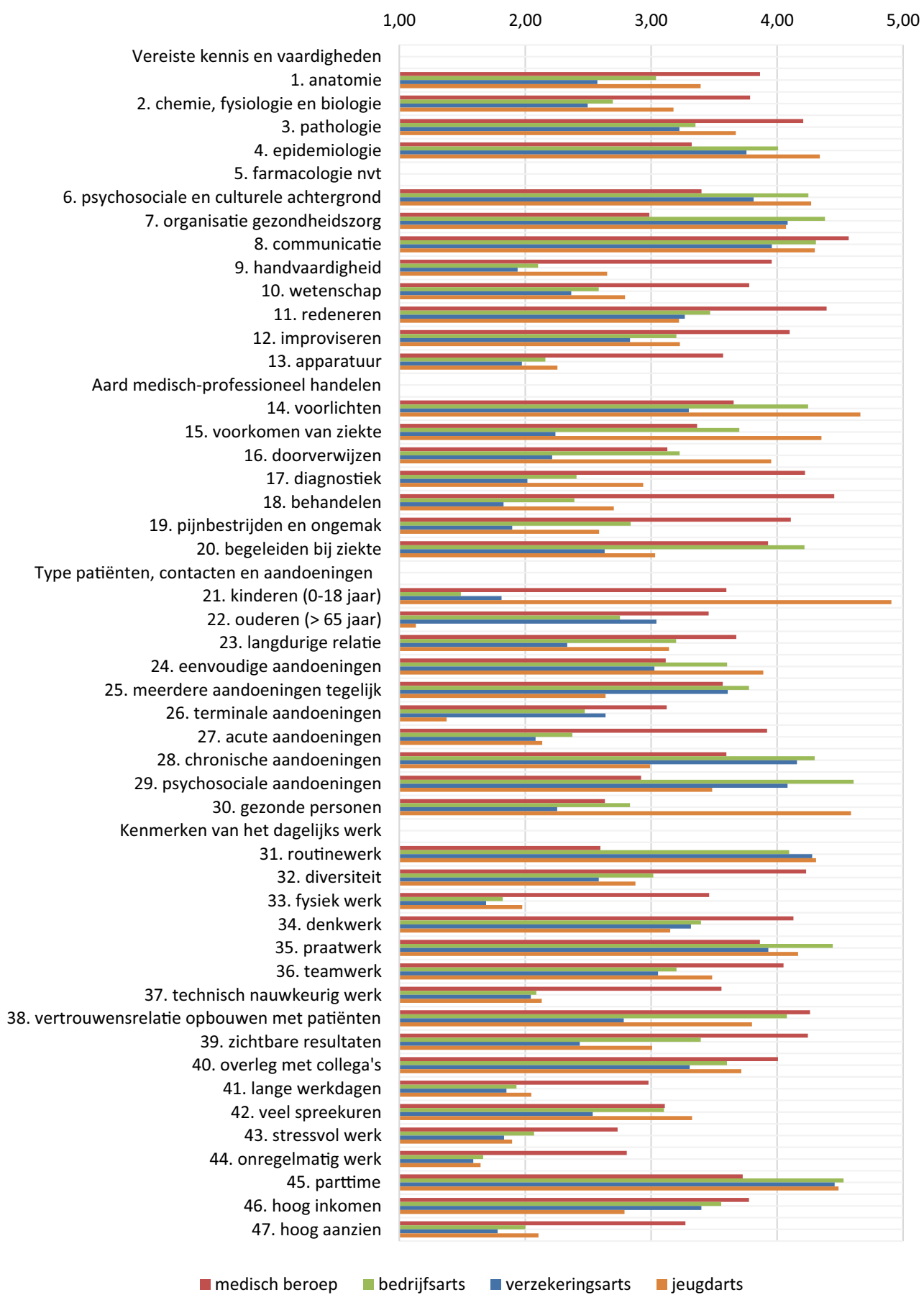

een praktijkstage bedrijfsgeneeskunde, verzekeringsgeneeskunde of jeugdgezondheidszorg in het coassistentschap doorlopen hebben (respectievelijk $n=33$, $n=16$ en $n=46$ ) was dit percentage opgelopen tot respectievelijk 85\% (2009: 83\%), 88\% (2009: 100\%) en 87\% (2009: 87\%). Er waren geen significante verschillen wat betreft kennis over deze disciplines tussen mannen en vrouwen (niet in de tabel).

In tab. 1 zijn de tien meest aantrekkelijke kenmerken van het medisch beroep in 2019 vergeleken met de kenmerken die het meest van toepassing werden geacht op het beroep van bedrijfsarts, verzekerings- arts en jeugdarts. Hieruit blijkt dat tot de meest aantrekkelijke kenmerken van het toekomstige artsenberoep behoren: 'het kunnen communiceren met patiënten' en 'het behandelen van patiënten'. Deze uitkomsten waren nagenoeg identiek aan die van tien jaar geleden. 'Psychosociale aandoeningen van patiënten' en 'Parttimewerkmogelijkheden' zijn volgens de studenten de belangrijkste kenmerken van het beroep van bedrijfsarts. 'Parttimewerkmogelijkheden' en 'routinewerk' zijn de belangrijkste kenmerken van het beroep van verzekeringsarts en 'jonge patiënten' en 'voorlichten' zijn volgens de responderende studenten 
Figuur 4 Gemiddelde verschilscores tussen de aantrekkelijkheid van kenmerken van het artsenberoep (nullijn) en de mate van toepasselijkheid hiervan op de beroepen van bedrijfsarts, verzekeringsarts en jeugdarts volgens studenten geneeskunde in $2019(n=145)$

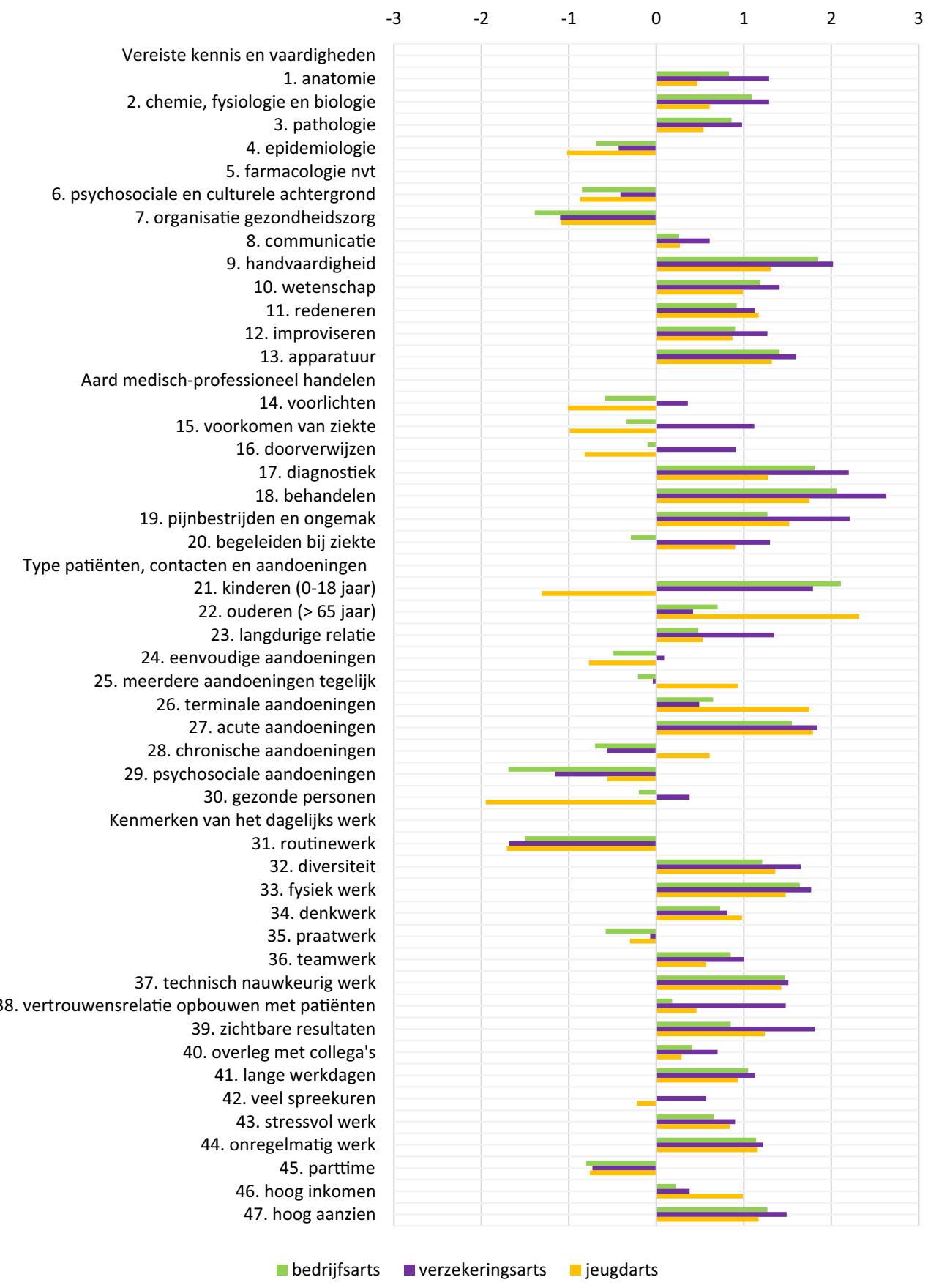

de belangrijkste kenmerken van het beroep van jeugdarts. Figuur 3 betreft een scorelijst van alle 47 items.

Figuur 4 laat de gemiddelde verschilscores zien van de kenmerken van het toekomstige beroep als arts (als een nullijn) en de toepasselijkheid hiervan op de beroepen van bedrijfsarts, verzekeringsarts en jeugdarts volgens studenten in 2019. De grootste discrepantie werd gevonden voor de beroepskenmerken 'het behandelen van patiënten' en 'het verrichten van diagnostiek'. Deze kenmerken met een grote positieve verschilscore zijn aantrekkelijk voor het toekomstige beroep van arts, maar zijn volgens de respondenten slechts in geringe mate van toepassing op de be- roepsuitoefening van de bedrijfsarts, verzekeringsarts en jeugdarts. 'Routinewerkzaamheden' zijn met een grote negatieve verschilscore het minst aantrekkelijk voor de latere beroepsuitoefening, maar volgens de respondenten wel in grote mate van toepassing op de beroepsuitoefening van de bedrijfsarts, verzekeringsarts en jeugdarts.

\section{Beschouwing}

De beroepen van bedrijfsarts, verzekeringsarts en jeugdarts zijn niet erg populair als latere beroepskeuze voor studenten geneeskunde. De belangstelling 
voor de beroepen van bedrijfsarts en verzekeringsarts lijkt de laatste tien jaar licht toegenomen, terwijl die voor jeugdarts wat achter lijkt te blijven. De respondenten geven aan weinig kennis van de inhoud van deze beroepen te hebben, maar deze kennis is hoger als ze een praktijkstage bij het betreffende vakgebied hebben gedaan. De respondenten willen later als arts het liefst goed kunnen communiceren met patiënten en deze ook graag behandelen. Qua werkomstandigheden zijn een vertrouwensrelatie opbouwen met patiënten en zichtbare resultaten in het werk belangrijk. Psychosociale aandoeningen en parttimewerkmogelijkheden zijn naar de mening van studenten voornamelijk van toepassing op de beroepen van bedrijfsarts en verzekeringsarts, en jonge patiënten op het beroep van jeugdarts. De meeste kenmerken die studenten aantrekkelijk vinden voor hun latere beroepsoefening zijn volgens hen niet van toepassing op de beroepen van bedrijfsarts, verzekeringsarts en jeugdarts.

De geringe voorkeur van geneeskundestudenten voor de beroepen van verzekeringsarts, bedrijfsarts en jeugdarts komt overeen met eerder onderzoek [3-8]. Hoewel de belangstelling wel enigszins lijkt toe te nemen, zal dit waarschijnlijk onvoldoende zijn om de toenemende tekorten op de arbeidsmarkt en de hiervoor noodzakelijke instroom in de vervolgopleiding te kunnen realiseren [1]. Ook diverse initiatieven die de afgelopen jaren zijn ondernomen om de aantrekkelijkheid van het vakgebied sociale geneeskunde te vergroten en om de instroom in de vervolgopleiding te vergroten hebben daar geen verandering in gebracht [12-14].

Studenten lijken ook een slecht beeld te hebben van de beroepen van verzekeringsarts, bedrijfsarts en jeugdarts. De meest waarschijnlijke oorzaak hiervan is dat slechts een klein deel van de studenten daadwerkelijk in aanraking komt met de beroepspraktijk van deze artsen. Deze indruk wordt versterkt doordat studenten die wel een praktijkstage in het betreffende vakgebied doen beter bekend zeggen te zijn met deze beroepen. Dankzij praktijkervaringen kunnen studenten deze disciplines in een bredere context (onder andere werkveld) plaatsen, dan wanneer ze deze vakgebieden slechts kennen vanuit een meer theoretisch kader. Dit betekent dat deze disciplines voldoende 'zichtbaar' moeten zijn in het medisch curriculum. Dit kan enerzijds door enthousiaste beroepsbeoefenaren bij het onderwijs te betrekken en anderzijds door de mogelijkheden voor praktijkonderwijs in deze disciplines te vergroten. In het nieuwe Raamplan 2020 met de eindtermen voor de artsopleiding lijken hiervoor voldoende aanknopingspunten te zijn [15]. Ook studenten pleiten voor meer aandacht voor sociale geneeskunde in het geneeskundeonderwijs [16, 17]. Het beroepsveld Maatschappij en Gezondheid is erg versnipperd, met een vierjarige opleiding tot arts Maatschappij en Gezondheid (tweede fase), waaronder een achttal tweejarige profielopleidingen (eerste fase). Mogelijk dat de nieuwe, integrale vierjarige vervolgopleiding Maatschappij en Gezondheid, die hopelijk binnenkort van start zal gaan, een meer eenduidig beroepsbeeld voor aankomende artsen zal bieden [18].

Het 'behandelen van patiënten' en 'het verrichten van diagnostiek' behoren volgens studenten tot de meest aantrekkelijke kenmerken voor de latere beroepsuitoefening als arts, terwijl deze kenmerken slechts in geringe mate van toepassing worden gevonden op de beroepen van bedrijfsarts, verzekeringsarts en jeugdarts. Om deze beroepen aantrekkelijker te maken voor een latere carrière zouden deze aspecten meer aandacht moeten krijgen. Dit kan bijvoorbeeld door het diagnostisch proces en de noodzakelijke medische kennis die daarbij nodig is explicieter naar voren te laten komen in patiëntcontacten in aanwezigheid van studenten. De huidige coassistentschappen sociale geneeskunde zijn in Nederland in het algemeen en het VUmc in het bijzonder relatief kort in vergelijking met klinische coassistentschappen. Wanneer coassistentschappen langer zijn, kan meer aandacht worden besteed aan zichtbare resultaten en het opbouwen van een vertrouwensrelatie met de patiënt.

In hoeverre de beeldvorming van studenten overeenkomt met de daadwerkelijke activiteiten van bedrijfsartsen, verzekeringsartsen en jeugdartsen is niet onderzocht. Nader onderzoek zal moeten uitwijzen of de beeldvorming van deze beroepen ook daadwerkelijk overeenkomt met de werkzaamheden van deze artsen. Eerder onderzoek liet zien dat er verschillen waren in de beeldvorming van studenten wat betreft het beroep van jeugdarts en het beeld van het beroep van de beroepsgroep zelf, zodat de veronderstelde kennis van studenten met betrekking tot een bepaald beroep met de nodige voorzichtigheid geïnterpreteerd moet worden [19].

Dit onderzoek kent sterke kanten en beperkingen. Een sterk punt is dat in beide cohorten gebruik is gemaakt van een identieke vragenlijst, waardoor goed inzicht wordt verkregen in de verschillen die de afgelopen tien jaar zijn ontstaan. Ook de hoge respons onder studenten is een sterk punt. De beperking van deze vragenlijst is evenwel dat andere belangrijke aspecten van de sociaalgeneeskundige beroepsuitoefening buiten beschouwing blijven, waaronder adequate arbeidsomstandigheden, zoals deeltijdwerk [8, 9]. Dit onderzoek vond plaats binnen een van de acht UMC's in Nederland die artsen opleiden. De gevonden resultaten kunnen daarom niet landelijk vertaald worden. Eerder onderzoek onder afgestudeerden heeft laten zien dat de UMC's wel degelijk verschillen wat betreft belangstelling voor sociale geneeskunde [8]. Het blijft belangrijk om nader onderzoek te doen bij andere faculteiten en de wijze waarop de belangstelling voor sociale geneeskunde na het afstuderen verloopt (landelijk) te monitoren. Gelukkig lijkt, overall, de belangstelling onder afgestudeerde artsen 
voor sociale geneeskunde iets toe te nemen vergeleken met een aantal jaren geleden [8]. Ook jonge artsen die bedrijfsarts of verzekeringsarts willen worden zijn positief over hun werk [20].

\section{Conclusie}

Dit onderzoek laat zien dat zowel faculteiten als het beroepsveld een rol spelen bij het adequaat onder de aandacht brengen van het beroep van sociaal geneeskundige bij studenten geneeskunde en dat deze partijen een gezamenlijke verantwoordelijkheid hebben om voldoende instroom in de sociaalgeneeskundige vervolgopleiding te kunnen realiseren.

Open Access This article is licensed under a Creative Commons Attribution 4.0 International License, which permits use, sharing, adaptation, distribution and reproduction in any medium or format, as long as you give appropriate credit to the original author(s) and the source, provide a link to the Creative Commons licence, and indicate if changes were made. The images or other third party material in this article are included in the article's Creative Commons licence, unless indicated otherwise in a credit line to the material. If material is not included in the article's Creative Commons licence and your intended use is not permitted by statutory regulation or exceeds the permitted use, you will need to obtain permission directly from the copyright holder. To view a copy of this licence, visit http://creativecommons.org/licenses/by/4.0/.

\section{Literatuur}

1. Capaciteitsorgaan. Capaciteitsplan 2021-2024. Deelrapport 4. Sociaal Geneeskundigen. Utrecht: Capaciteitsorgaan; 2019.

2. European Parliament. Directive 2005/36/EC of the European Parliament and of the council. Brussel: European Parliament; 2005 .

3. Soethout MBM, Ten CateTJ, Van derWal G. Development of interest in a career in public health during medical school. Public Health. 2008;122(4):361-6.

4. Soethout MBM. Een carrière als bedrijfsarts of verzekeringsarts; niet voor de huidige geneeskundestudent. Tijdschr Bedrijfs Verzekeringsgeneeskd. 2010;18(1):4-8.

5. Soethout MBM. Een carrière als jeugdarts: een optie voor de huidige geneeskundestudent? Tijdschr Jeugdgezondheidsz. 2010;1(42):11-5.
6. Svirko E, Goldacre MJ, Lambert T. Career choices of the United Kingdom medical graduates of 2005, 2008 and 2009; questionnaire surveys. Med Teach. 2013;35:365-75.

7. Lambert TW, Goldacre MJ, Turner G. Career choices of United Kingdom medical graduates of 2002: questionnaire survey. Med Educ. 2006;40:514-21.

8. Velde F van der, Leemkolk B van de, Lodder A. Loopbaanwensen en loopbaanvoorkeuren basisartsen. Meting 2019. Utrecht: Prismant; 2019.

9. Soethout MB, Wal G van der, Cate TJ ten. Carrièrewensen en beroepskeuze van recent afgestudeerden artsen. Ned Tijdschr Geneeskd. 2007;151(38):2118-23.

10. Maiorova T, Stevens F, Scherpbier A, et al. The impact of clerkships on students' specialty preferences: what do undergraduates learn for their profession? Med Educ. 2008;42(6):554-62.

11. NieuwhofMG, Rademakers JJ, Kuyvenhoven MM, et al. Student's conceptions of the medical profession; an interview study. Med Teach. 2005;27(8):709-14.

12. Schippers EI. Kamerbrief over opleidingen publieke gezondheid. Den Haag: Ministerie van Volksgezondheid, Welzijn en Sport; 2016.

13. Tweede Kamer. Rapport aanpak dreigend tekort bedrijfsartsen. Den Haag: Tweede Kamer; 2017.

14. Ark T van. Kamerbrief voortgang arbeidsgerelateerde zorg. Den Haag: Ministerie van Sociale Zaken en Werkgelegenheid; 2016.

15. Pol M van de, Hacfoort M, Laan R. Raamplan artsopleiding 2020: arts van de toekomst bevordert en beschermt gezondheid. Utrecht: Nederlandse Federatie van Universitair MedischeCentra; 2020.

16. Acem I. Onderbelichte vervolgopleidingen. Utrecht: De Geneeskundestudent; 2018.

17. Boroumand S, Stein MJ, Jay M, et al. Addressing the health advocate role in medical education. BMC Med Educ. 2020;20:28.

18. Koepel Artsen Maatschappij en Gezondheid. Opleidingsplan arts Maatschappij en Gezondheid 2020. Utrecht: Koepel Artsen Maatschappij en Gezondheid; 2020.

19. Soethout MBM, Cate TJ, Wal G van der. Correlations of knowledge and preference of medical students for a specialty career: a case-study of youth health care. BMC Public Health. 2008;8(1):14.

20. Greijn C, Gulden J van der. Wat verwachten jonge artsen die bedrijfsarts of verzekeringsarts willen worden van hun werk en hun werkgever? Tijdschr Bedrijfs Verzekeringsgeneeskd. 2016;24:1504. 